\title{
Assessing and Explaining the Diverging Trajectories of Territorial Parties and Politics in Italy and Spain (2008-2018)
}

Davide Vampa and Caroline Gray 
Until the mid-2000s, territorial politics played a considerable role in both Italy and Spain. Two regionalist parties, among others, clearly contributed to this: Democratic Convergence of Catalonia (CDC) and the Northern League. Yet evidence shows that the two parties, while starting from relatively similar positions, have followed diverging trajectories, particularly after the financial (and then economic) crisis that hit their respective countries. CDC pushed its pro-autonomy stances to the extreme and eventually ended up supporting Catalan independence. On the other hand, the League dropped its regionalist agenda and even became a state-wide party. By comparing these two cases, this article aims to shed light on the mechanisms that lead to the radicalisation or moderation (and even abandonment) of regionalist parties' territorial demands. These opposite movements have broader implications, since they have been accompanied by increasing polarisation of territorial politics in Spain and the depoliticisation of this issue in Italy.

Keywords: territorial politics, Italy, Spain, independence, regionalism 


\section{Introduction}

For most of the 1990s and early 2000s, Italy and Spain were regarded as the two main European countries where territorial issues had come to play an important role in shaping national and sub-national politics. They both experienced the rise of strong regionalist and sub-state nationalist parties (De Winter and Türsan 1998) and underwent a significant process of institutional regionalisation (Keating 2009). Although pro-independence movements were not completely absent, demands coming from most regionalist parties were aimed at achieving increasing institutional autonomy, rather than full independence. In sum, both countries were characterised by significant elements of territorial dynamism, which, however, did not seem to seriously destabilise political and institutional equilibria.

Two regionalist parties played a particularly important role in these two contexts. In Italy, the Northern League (LN) advocated increasing autonomy for northern Italy and was particularly strong in Lombardy and Veneto, the two richest and most populous regions of the North. In the late 1990s this party even campaigned for the full independence of this part of the country (Diamanti and Donaldson 1997) but then returned to its original support for more moderate forms of devolution at the beginning of the $21^{\text {st }}$ century. In Spain, Catalonia was by far the largest region with significant territorial mobilisation. Here, Democratic Convergence of Catalonia $(\mathrm{CDC})^{1}$, which was included in the electoral alliance Convergence and Union (CiU), dominated the pro-autonomy camp. Apart from the short secessionist parenthesis of the LN, both parties were clearly supportive of increasing institutional decentralisation in their respective countries, without questioning national unity.

Yet, since the late 2000s, the trajectories of these two political actors have diverged considerably, even though Italy and Spain seemed to face similar challenges during and in the aftermath of the Great Recession. While the LN dropped most of its pro-autonomy and federalist agenda and transformed into a state-wide party, CDC moved in the opposite direction, increasing its territorial demands and eventually supporting Catalan independence. The questions that this article aims to address are: Why has this occurred? What are the mechanisms that have led to these opposite outcomes?

Answering these questions is particularly relevant because it can provide important insights into more general transformations in the political systems of both countries. Indeed, while in

\footnotetext{
${ }^{1}$ Rebranded since 2016 as the Catalan European Democratic Party (PDeCAT).
} 
Spain we can observe an exacerbation of centre-periphery tensions since 2008, in Italy the federalist and regionalist agenda has been significantly de-politicised and has almost completely disappeared from the political debate in the same period.

In this study we explain the divergence outlined above by looking at how contextual socioeconomic and political factors have impacted on the strategies pursued by two important regionalist parties. Italy and Spain allow a systematic comparison of 'most similar systems' (Della Porta 2008: 214-217) and this offers a unique opportunity, so far surprisingly ignored by the literature, to identify factors leading to a radicalisation or de-radicalisation of territorial political demands.

In this article we first show that the League and CDC have moved in opposite directions, starting from very similar territorial stances in the 1990s. Then we develop a theoretical framework aimed at explaining the two different outcomes by linking changes in socioeconomic and political contexts to the adjustments made by the two regionalist parties under their 'transformative' leaders. Based on this framework, our empirical analysis traces the diverging paths towards radicalisation or moderation of territorial mobilisation by considering the role played by both structural factors and political agency. In the conclusion we stress that assessing the evolution of the two parties is important if we want to fully appreciate the striking differences between Italy and Spain in the salience and polarisation of centre-periphery relations after the crisis. We also suggest that the framework presented in this study can be applied to other cases to understand how and why regionalist parties (but also state-wide ones) change their political stances on the territorial dimension.

\section{Northern League and Democratic Convergence of Catalonia before and after the crisis}

Until recent years two parties played a key role in the autonomist camp of Italy and Spain: the LN and CDC. The first of these became successful in the early 1990s thanks to a confluence of various regional movements representing the Italian North (Biorcio 2017: 135), among which the Lombard League was the largest one. The second was the major partner of an electoral coalition and later party federation called Convergence and Union (CiU), which was created in the late 1970s and was, by far, the largest regionalist group of Spain. ${ }^{2}$ CDC was

\footnotetext{
${ }^{2}$ At its peak $\mathrm{CiU}$ obtained $5 \%$ of the national vote in General elections. Its closest equivalent in the Basque region, the Basque Nationalist Party (PNV), never managed to obtain more than $1.6 \%$ of the vote nationally.
} 
defined as a 'moderate regionalist' party (Barberà and Barrio 2017) advocating more selfgovernment for Catalonia and emphasising economic and political grievances against Madrid, while downplaying its 'ethnic appeal' (Ibid.: 69). The LN was very similar in this respect. Like $\mathrm{CDC}$, this party represented one of the richest areas of the country and, therefore, accused Rome, and the South more generally, of 'exploiting' the North. Generally, both parties focused on the territorial allocation of financial resources between centre and periphery. In both cases, central governments were accused of taking away resources from productive regions to redistribute them to less productive ones.

Therefore it is not surprising that $\mathrm{LN}$ and CDC (as part of $\mathrm{CiU}$ ) used to be equally supportive of decentralisation. Figure 1 shows how their positions on the territorial organisation of their respective countries have changed from the 1990s to the 2010s. This is based on data from the Comparative Manifesto Project (Volkens et al. 2018), which refer to the relative share of statements (quasi-sentences) supporting decentralisation/federalism in relation to all statements in the party manifesto. ${ }^{3}$ The number can range from 0 to 100 and a higher share indicates a more marked preference for transferring authority from the centre to the regions.

[Figure 1 about here]

What is striking is the increasing divergence between the two parties, which became clearly evident in the post-crisis period (in the 2010s). In the 1990s the League and CDC were almost identically positioned on the centre-periphery political dimension but then followed trajectories that are basically symmetrical. Whereas the former has abandoned most of its pro-federalist agenda (Albertazzi, Giovannini and Seddone 2018), the latter has placed even more emphasis on territorial issues and eventually adopted pro-independence positions. The Northern League became the League, dropping any specific reference to the North in its logo and becoming a key member of the growing family of right-wing national populists (Vampa 2017). On the other hand, the moderate $\mathrm{CiU}$ was disbanded and $\mathrm{CDC}$ ran in several pro-independence electoral coalitions, while re-founding itself as an explicitly independentist party (Colomer 2017: 964).

As highlighted by Elias, Szöcsik and Zuber (2015: 844), parties 'choose not only which dimensions to compete on (positioning), but also how much emphasis they place on each dimension (selective emphasis)'. Using their framework, we can say that CDC reinforced its 'unidimensional' strategy, focusing on territoriality and radicalising its position on this

\footnotetext{
3 'Support for federalism/decentralisation' is measured by calculating the difference between category 301 (Federalism) and 302 (Centralisation) of the Comparative Manifesto Project.
} 
dimension. On the other hand, the LN not only moderated its position on the territorial dimension but also 'blurred' it, while placing new emphasis and radicalising on the libertarianauthoritarian dimension, which is key for populist radical right parties (De Lange 2007).

Why has this happened? The contexts in which the two parties operated were not so different after all. Both Italy and Spain experienced a deep economic crisis in the post-2008 years, which resulted in an equally serious political crisis. Many citizens were disillusioned with the mainstream consensus embraced by both government and opposition, and voted instead for alternative parties (Hernández and Kriesi 2016; Hobolt and Tilley 2016). The elections in Italy and Spain since 2008 provide a clear picture of how radically political dynamics in the two largest countries of Southern Europe changed in a short period of time. In the Spanish party system, which used to be among the most stable and least fragmented in Europe, combined support for the two mainstream (left and right) parties declined progressively from $84 \%$ in 2008 to $45 \%$ at the April 2019 election, recovering slightly to $49 \%$ at the November 2019 electoral repeat. In Italy the collapse was similar in size over roughly the same time period: from $70 \%$ in 2008 to $33 \%$ in 2018.

In sum, in a period of great economic uncertainty, both political systems were under significant pressure. They were both characterised by high levels of electoral fluidity, with the rise of new challenger parties. Yet this apparently similar set of conditions did not trigger similar responses from the League and CDC. In order to solve this puzzle, we need to develop a framework which allows a systematic empirical analysis of the two case studies. We should start from the 'shock' of the crisis and then move along the chain of structural transformations and agents' responses which have determined a radical re-orientation of once relatively similar territorial agendas.

\section{Linking the external shock to changing party positions on the territorial dimension}

The two main regionalist parties of Italy and Spain have clearly redefined their priorities in the post-crisis period. Yet this change has not occurred in a vacuum. We argue that their shifts on the territorial dimension of political competition have been driven by 'medium-term' changes within the political opportunity structures (Kitschelt 1986), which have also interacted with leadership agency and intra-party dynamics.

Figure 2 shows the hypothesised causal chain leading to the current reconfiguration of party positions in Italy and Spain. The first segment of the chain focuses on the macro-level, socio- 
economic changes that occurred as a consequence of the financial and economic crisis started in 2007 (stage 1). We argue that the effects of the exogenous shock, combined with domestic economic trends that started in the pre-crisis period (A), resulted in a change in the mediumterm political opportunity structures (stage 2), which include: the characteristics and ideological position of competitors in the party system, the degree of convergence between the mainstream parties and the coalition format in the respective party systems (Arzheimer and Carter 2006: 423). More generally, the Great Recession was not only an economic crisis but also had significant political implications (Hutter and Kriesi 2019). Economic hardship, and its social consequences, prompted voters to move away from incumbents and try to find new political alternatives (Casal Bertoa 2014: 5). This de-alignment was accompanied by a redefinition of patterns of political competition and the rise of new parties and movements campaigning against the political establishment and for a regeneration of democracy (Scantamburlo, Alonso and Gómez 2018: 615). When the crisis hit, the League and CDC were regarded as an integral part of the pre-existing political system (Scantamburlo, Alonso and Gómez 2018: 637). Therefore, like other established parties, they had to develop strategies to respond to the challenges posed by the changing political environment. Of course, the fractures that emerged after the crisis were not completely new. Some had deeper roots and were connected to pre-crisis trends and legacies at national and subnational levels (B). Therefore the crisis might have led to an acceleration of pre-existing processes of political de-/realignment and party system change (Hernández and Kriesi 2016: 204).

Our analysis, however, focuses on particular aspects of the socio-economic and political contexts. As we mentioned in the previous section, at first Italy and Spain seem to have experienced similar economic and political shocks. Yet, since in this study we want to understand why two regionalist parties have diverged so much in their approach to autonomy and federalism, our focus is on the territorial consequences of the socio-economic and political crises. Therefore, we consider how regional finances and fiscal relations between centre and periphery were affected by the economic storm (stage 1) and how new political actors, which emerged in the aftermath of the Great Recession, approached the centre-periphery cleavage (stage 2). By looking at these two specific aspects, we show that there are clear differences between the two cases, which may in turn help us explain the diverging outcomes.

The political transformations that occurred after the Great Recession clearly constituted a 'critical juncture' (Capoccia and Kelemen 2007), that is, a political phase in which party leaders 
(individual personalities or groups) may play a key role as 'agents' of change (stage 3). Political 'entrepreneurs' - those 'individuals who change the direction and flow of politics' (Schneider and Teske 1992: 737) - can use the opportunities (or challenges) provided by a restructuring political system to emphasise or de-emphasise some issues and recalibrate the long-term priorities and strategies of the organisations they lead. In some cases they can do so by drawing on organisational and programmatic legacies or accelerating processes of internal reform that may have already started (but did not fully unfold) before the crisis (C). Again, the focus is on how party leaders re-interpreted the territorial dimension of politics, since it is on this dimension that we observe a clear divergence between CDC and the League.

[Figure 2]

The last step of Figure 2 is the outcome (4), that is, the change in party positions on the territorial dimension and the emphasis they place on it (see Elias, Szöcsik and Zuber 2018, mentioned above). We have already discussed this outcome in the previous section describing the transformation of CDC and LN. By focusing on steps 1, 2 and 3 in Figure 2, we can explain this transformation. This is what we are doing in the next three sections. In the conclusion we also discuss the existence of a possible feedback effect (the arrow moving back from stage 4 to stage 2 in Figure 2). Indeed, the repositioning of the two parties might in turn have contributed to reshaping the structure of political competition in the two countries.

\section{Stage 1. The economic crisis in Italy and Spain}

The economies of both Italy and Spain suffered significantly, but not in the same way, in the period that followed the 2007 financial shock. When the Great Recession hit Italy, the country was already in a rather delicate economic position, with low levels of economic growth and a very high debt/GDP ratio. The crisis contributed to the worsening of this situation, although Italian governments managed to limit the increase in yearly budget deficits and unemployment remained in line with that of the Eurozone (which in the post-2008 period was on average above $10 \%$, so at relatively high levels). Spain instead started from a much better position, with a pre-crisis period characterised by sustained economic growth (well above the Eurozone average) and a healthy financial outlook (even running budget surpluses). However, the situation soon deteriorated in this country. Budget deficits and unemployment skyrocketed in 
the post-crisis period. Generally it is true that the short-term consequences of the crisis were serious in both countries. Yet the change, and the consequent adjustment required, seemed more dramatic in the Spanish case.

Indeed, as a consequence of a rapidly deteriorating financial situation in Spain, concerns grew over Spanish regional budgets in particular from 2010. Spain's regional governments manage more than a third of state expenditure (Castells 2014: 281), but many remained reluctant to reduce spending once the Spanish government had started to implement austerity measures. The combination of extensive devolved spending powers and a primarily centralised revenueraising system, which applies to 15 of Spain's regions under the common financing system (all except the Basque Country and Navarre), is a well-known risk for weakening fiscal discipline (Rodden 2005), and yet the situation was more complex than this. The regions faced a tougher task than the central government to trim their budgets since around two thirds of their spending is on the fundamental policy areas of health, education and social services. These were far harder to control demand for and cut than areas being slashed at the time by the central government, such as public investment in infrastructure, civil servants' salaries and the foreign office budget (Gray 2014).

Italian regions, on the other hand, despite facing challenges associated with the negative effects of the recession (lower revenues, worsening social conditions), did not experience the same level of pressure in a short period of time. Indeed, Italy started to enforce fiscal discipline much earlier and focused on the containment of budget deficits before the beginning of the financial crisis to reduce its historically high national debt, which had significantly increased in the 1980s and 1990s.

Figure 3 summarises the pre-crisis (2000-2007) and post-crisis (2008-2015) fiscal situation in Italian and Spanish regions. The difference between spending and revenues, measuring surplus/deficit, is calculated as a percentage of the revenues received by a region in a given year (Asatryan Feld and Geys 2015). Higher scores mean that the region is overspending (i.e. deficit is higher). Interestingly, Italian regional deficits did not increase substantially after the crisis. In fact, in the two core regions of northern Italy, which are also the LN's strongholds, deficits even declined (Lombardy) or turned into surpluses (Veneto) after 2008. This situation of relative stability may have contributed to containing territorial conflicts over the distribution of resources, thus reducing the saliency of the centre-periphery cleavage. On the other hand, Spanish regional budgets became much more unbalanced in the post-crisis period. Moreover, 
Catalonia was among the regions most seriously affected by the financial storm. Consequently, it also became one of the regions most dependent on loans from the central Spanish government from 2012 onwards, once it had lost access to alternative sources of financing (Gray 2014: 3538). In return, it had to adhere to a strict adjustment programme set by the Spanish government, as part of the latter's efforts to meet the deficit targets set by the EU for Spain overall. This intensified longstanding Spanish-Catalan government tensions over the redistribution mechanisms inherent in the regional financing system (Gray 2014; 2016).

\section{[Figure 3]}

In sum, in a context of general economic depression, the discrepancy between pre- and postcrisis economic and financial trends was much more marked in Spain than in Italy. As a result, several Spanish regions, in particular Catalonia, were also subject to much more pressure than Italian ones. The worsening economic situation in turn had an impact on patterns of party competition, acting as a catalyst for processes of political de-/realignment already underway, as shown in the next section.

\section{Stage 2. Changing political opportunity structures}

The Italian political scenario during the Great Recession was characterised by the crisis of the established party system and the rise of a new important political actor, the 5 Star Movement (M5S). Verbeek, Zaslove and Rooduijn (2018) provide an account of how the 'meta-structure' of party competition changed as a consequence of the crisis and emergence of a new populist actor. In the 1990s and 2000s, after the rise of the LN and the establishment of Berlusconi's Forza Italia, a 'bipolar' party system with two alternating centre-left and centre-right coalitions emerged. The LN also acted as a populist political force linking an 'us versus them' political discourse to campaigns supporting increasing autonomy (and even independence) for the wealthy regions of the North. The regionalist populism of the League forged an alliance with the neoliberal populism of Berlusconi. By becoming a key player in the centre-right political coalition, the League was able to promote regionalism and federalism as a central issue in the political agenda. ${ }^{4}$ Yet, at the same time, the alternation between centre-left and centre-right

\footnotetext{
${ }^{4}$ In fact also the centre-left coalition embraced the federalist agenda and approved a constitutional reform increasing the powers of regions in 2001.
} 
turned both alliances into established elites, which, in a context of economic uncertainty, created opportunities for a new wave of populism represented by the M5S.

In contrast, in Spain, CDC, as lead party of the Catalan nationalist federation CiU, never became a permanent part of a state-wide party alliance. Rather, its relationship with state-wide parties - and, in turn, the importance granted to the territorial question in state-level politics waxed and waned throughout the 1990s and 2000s depending in large part on whether the party governing Spain had an absolute majority of seats in the Spanish parliament or not. On occasions where the governing party, be it the People's Party (PP) or the Socialist Party (PSOE), fell short of an absolute majority, it would seek support from regionally-based parties in return for decentralisation gains (and/or support in the regional parliament where necessary) via 'mutual backscratching' arrangements (Field 2014). Such deals gave the Catalan nationalists' extensive leverage over the Spanish government at certain times, but left them with little-to-no leverage when the PP government had an absolute majority in 2000-2004 and again in 2011-2016, during which periods the PP's centralist vision came to the fore. Many within CDC see the origins of the party's later turn to a pro-sovereignty agenda in the first absolute majority Spanish PP government of Aznar in 2000-2004, which marked the beginnings of a reassertion of the Spanish nationalist vision of 'one nation' and a move towards recentralisation. ${ }^{5}$

Moreover, it became increasingly difficult, for both ideological and strategic reasons, for Catalan nationalists to support PP minority governments - or indeed rely on the PP's support back home in the Catalan parliament - following an increase in left-right political polarisation that took place under the Socialist governments of José Luis Rodríguez Zapatero from 2004 onwards. From Zapatero's first mandate (2004-2008), a period described by Encarnación (2009) as marking 'Spain's New Left Turn', the left-right divide in Spain became markedly more entrenched, as the PP reacted against several measures taken by the Socialists in quick succession to reform policies and institutional arrangements that had been in place since Spain's transition to democracy. In Spain, the left-right axis of competition incorporates the centre-periphery axis, with left- and right-wing ideologies among state-wide parties long associated with decentralist and centralist positions, respectively (Dinas 2012). Thus, one of the 'new-left' policies of Zapatero that the Spanish right vehemently opposed was his decision

\footnotetext{
${ }^{5}$ Personal interviews with CDC politicians, 2015-2016.
} 
to revise and update the regional statutes of several autonomous communities and devolve further powers to some of them (Muro 2009).

In practice, Zapatero faced immense challenges throughout the process, due in large part to regions with strong nationalist movements presenting statute reform proposals that were rejected by the Spanish parliament and/or Constitutional Court. In the Catalan case, the initial watering down of the Catalan parliament's draft statute in order to secure Spanish parliamentary approval in 2006, which served to reduce the greater fiscal devolution the region sought (Gray 2016: 215-224), was followed later by a 2010 Spanish Constitutional Court ruling that declared totally or partly unconstitutional several articles of the new Catalan statute. This was the result of various appeals, some lodged by the PP, against aspects of the statute considered by critics as unconstitutional. The politics of the statute reform process (Muro 2009, Keating and Wilson 2009) led to increasingly polarised dynamics between pro-Spain and proCatalonia parties - far more so than in the Basque case, due to circumstances specific to that region. This polarisation was exacerbated further by the outbidding process whereby the two Catalan regionalist-nationalist parties, CDC and the Republican Left (ERC), sought to outdo each other with more territorial ambitious proposals during the statute reform process and beyond (Barrio and Rodríguez-Teruel 2017; see also Stage 3).

These differences in the Italian and Spanish cases have contributed, in turn, to shaping the contrasting ways in which the strengthening of challenger parties focusing on new politics issues has led to a redefinition of political cleavages and patterns of political competition at both national and regional levels. Scantamburlo, Alonso and Gómez (2018) suggest that the increasing relevance of democratic regeneration campaigns constitute a challenge for established regionalist parties (including the $\mathrm{LN}$ and $\mathrm{CDC} / \mathrm{CiU}$ ), which need to further diversify their political platform and take into account issues that relate to the improvement and transparency of democratic processes. The emergence of a new politics conflict dimension may in turn lead to declining relative importance of competition based on the traditional centreperiphery cleavage. This is particularly true if new (and successful) challenger parties do not pay particular attention to territorial politics, as in the case of the M5S. In Spain, however, the new parties have linked their political agenda in part to the unresolved territorial question, which has therefore remained salient. 
The two main new parties in Spain that emerged in the wake of the financial crisis, Ciudadanos ${ }^{6}$ and Podemos, positioned themselves further to the extremes of the territorial cleavage than the PP and PSOE, respectively. While Ciudadanos criticised the PP for not taking an even tougher line and action on Catalan secessionist actors, Podemos became the first state-wide party ever to have supported the 'right to decide' (in other words, self-determination) of Spain's constituent regions. On the right, this resulted in an outbidding process between the PP and Ciudadanos - later also involving Vox from 2018 - as to who would 'crack down' the hardest on the Catalan independence movement, thereby increasing further the salience of the territorial dimension of competition.

The new parties in Spain contributed to keeping centre-periphery issues high on the political agenda, much more than the M5S in Italy. The left side of Figure 4 shows manifesto data on how salient the centre-periphery cleavage is for Podemos and Ciudadanos in the Catalan context and for the new Italian party in the three main regions of northern Italy: Lombardy, Veneto, Piedmont. We refer to the centre-periphery dimension described in the codebook of the Regional Manifesto Project (Gomez, Alonso and Cabeza 2018). The right side of Figure 4 focuses on the position of the three parties: positive scores meaning support for more decentralisation, negative scores meaning support for centralisation. Again, Ciudadanos and Podemos have clearer (opposite) stances than the M5S.

\section{[Figure 4]}

Responses to bad regional governance have also been markedly different in the two countries. In Italy, one aspect that contributed to the rise of the M5S and its decision to de-prioritise the territorial dimension was precisely the crisis of legitimacy faced by Italian regional institutions, increasingly associated with a rather corrupt political class (Cerruto, 2013). After the crisis, almost all regional councils were involved in expenses scandals. The LN itself was involved in party funding scandals, one of which even involved Umberto Bossi, leader of the party for more than two decades, and forced him to resign in 2012. A Demos survey published at the end of 2014 showed that since 2010, Italians' support for regional institutions had dropped

\footnotetext{
${ }^{6}$ Ciudadanos was first founded in Catalonia in 2005/2006 to oppose the increasing dominance of Catalan nationalism, but it was not until the aftermath of the 2008 financial crisis that it successfully branched out to state-wide politics with a wider remit.
} 
from $33 \%$ to $19 \% .^{7}$ In this context the regionalist agenda of the LN became considerably less appealing. Interestingly, the constitutional reform promoted by the government led by centreleft leader Matteo Renzi (2014-2016) was aimed at addressing some of the dysfunctionalities associated with the post-2001 regionalised system. This was done by promoting 'a considerable rebalancing of power in favour of the central state' and marking 'a clear U-turn with respect to the federalist ideals that had accompanied the birth of the Second Republic' (Ceccarini and Bordignon 2017: 285). Yet this attempt to recentralise power, which was rejected by Italian voters in the 2016 constitutional referendum, did not contribute to an awakening of territorial competition and a 'systemic' re-politicisation of the centre-periphery cleavage. The role of regions in the new constitutional setting was not a central issue in the campaign leading to the referendum, which was mainly focused on support or opposition to the Renzi government (Ibid.: 295). The front rejecting the reform was very heterogeneous including the M5S, the League, Berlusconi's party and the extreme left, which were just united by their hostility to Renzi and lacked a common view on his re-centralisation plans (Vampa and Vignati 2017).

In Spain, the reaction to the corruption that surfaced among regional political elites, many of whom were found to have had far too cosy a relationship with the regional savings banks and construction firms, was quite different. The corruption uncovered at regional government level in several autonomous communities was, by and large, committed by regional representatives of the state-wide parties and therefore became part and parcel of the corruption scandals engulfing the PP in general, and to a lesser extent the PSOE, rather than a specifically regional phenomenon. In turn, the anti-corruption stance adopted by the new parties was against the corruption of the longstanding parties at all government levels. $\mathrm{CDC} / \mathrm{CiU}$ found itself in a difficult predicament since it too found itself tainted as one of the 'old' parties embroiled in corruption scandals, noticeably surrounding Jordi Pujol, former Catalan regional president for CDC/CiU from 1980-2003, and other CDC affiliates of that era. This was one among several factors that pushed CDC to speed up its rebranding of itself as a new pro-independence party under a new leadership (see Stage 3) and to distance itself from the centre-right Pujolist Catalan nationalism of the past, at a time when left-wing pro-independence forces were rapidly gaining popularity.

Of course, back in Italy, regional identities and pro-autonomy movements did not completely disappear in the heartland of LN support. For instance, in 2014 autonomous regional groups

\footnotetext{
${ }^{7}$ http://www.demos.it/a01077.php
} 
staged a referendum on Venetian independence. This vote was unconstitutional and was organised in an informal way. Although, due to the unconventional nature of the vote, no official data are available, the organisers claimed that turnout was very high (73.4 percent of eligible voters - much higher than in the 2017 Catalan independence referendum) and there was a plebiscitary support for independence (89 percent). According to some opinion polls, the majority of voters from all political parties supported independence. ${ }^{8}$ Following this first territorial mobilisation, in 2017 the regional governments of Veneto and Lombardy, led by the League, organised referendums - these were constitutionally legitimate - consulting citizens on their support for more autonomy. Both referendums returned overwhelming majorities (above 90\%) in favour of transferring more powers to the regions. Yet far from revitalising the centre-periphery cleavage, these initiatives just showed that there was a broad consensus in favour of autonomy since none of the state-wide parties (including the M5S) campaigned against the referendum (Giovannini and Vampa 2019). ${ }^{9}$ The success of the referendums was not used as an opportunity to advance meaningful institutional reforms in the immediate aftermath of the vote and was not even exploited as a central political issue in the general election campaign a few months later. This is in stark contrast to Catalonia, where partisan divisions over the national and territorial question were exacerbated by the Catalan independence referendum in 2017 (and various attempts at citizen consultation beforehand). Therefore, even similar episodes, like regional referendums (but also the corruption scandals involving both $\mathrm{LN}$ and $\mathrm{CDC}$ ), were not accompanied by comparable shifts in the territorial positions of the two parties. This is because, ultimately, the leaders of the two forces responded to the political crises affecting their respective countries (and regions) in different ways, as illustrated in the next section.

\section{Stage 3. Beyond structural factors: leaders and intra-party dynamics}

When Matteo Salvini became leader of the LN at the end of 2013 he inherited a significantly weakened organisational structure, which was more regionally concentrated than it had ever been in the previous two decades. The party received only $4 \%$ of the vote at the national level (back to its minimum since the early 2000s), even though it controlled the governments of the three main regions of the North: Lombardy, Veneto and Piedmont. Salvini's maiden speech as

\footnotetext{
${ }^{8}$ See http://www.demos.it/a00970.php

${ }^{9}$ In fact many local leaders of the mainstream centre-left and centre-right parties campaigned in favour of autonomy.
} 
leader at the LN conference in December 2013 was under a banner that read 'The Future is Independence' (Albertazzi, Giovannini and Seddone 2018: 649). Therefore, there was no sign that the party was moving away from its territorially focused political platform.

Yet within two years Salvini would radically reshape the political identity of the party and put aside the core regionalist character of the LN. Albertazzi, Giovannini and Seddone (2018) empirically show that in his political communication on social media, Salvini (but also the party organisation as a whole, which followed the leader) gradually de-emphasised the importance of themes linked to the traditional territorial focus of the party. Messages that resonated well beyond the North were instead privileged by the leadership. This shift in communication reflected a deeper ideological and organisational transformation of the party, which by the end of 2018, had resulted in the almost complete abandonment of a federalist, not to mention pro-independence, agenda.

In Catalonia, it was the year 2012 that marked a clear turning point in CDC's strategy away from the decades of accommodationist politics, as the then party leader Artur Mas explicitly started to advocate that the way forward for Catalonia involved achieving political sovereignty and some degree of statehood (the terminology used at this stage was still deliberately ambiguous to embrace options short of full independence too). $\mathrm{CDC} / \mathrm{CiU}$ then formed an alliance in the Catalan parliament with a pro-independence party (the Republican Left, ERC) for the first time with the goal of working towards a referendum. Thereafter, CDC's commitment to an independence agenda became firmer, resulting in 2015 in the break-up of CiU when the Democratic Union of Catalonia (UDC) - the smaller partner in the federation did not support CDC's new independentism and party alliances.

Why did these shifts in territorial agenda happen? In Stage 2 we highlighted that the changing political environment resulted from the crisis might have 'forced' the two parties to reconsider their position on the territorial dimension. Yet external political factors would have not been sufficient to push the League away from its core programmatic stance, or to push CDC away from its traditional accommodationist practices. Internal party factors also help us explain the parties' transformation.

The agency of the new LN leader, Salvini, should not be underestimated. Indeed, changing the identity of the party was instrumental to the establishment of his new leadership within a party that for more than 20 years had been dominated by the figure of Umberto Bossi and his allies. 
Most of Bossi's (former) loyalists could still rely on personal support and power positions in the northern regions of Italy and would continue to act as an important constraint to the new leadership. Expanding the territorial base of the party by involving constituencies in regions outside the North was therefore a necessary step which would allow Salvini to establish and consolidate his role. It is not a coincidence that his nationalisation strategy was accompanied by the creation of a parallel political list, to be presented in the southern regions, called Noi con Salvini (Us with Salvini) (Vercesi 2016: 400). The name and platform of the new 'sister party' highlighted the centrality of the leader in the process of territorial expansion and ideological transformation. In northern Italy, Salvini still had to accommodate the demands coming from well-established regional leaders, such as the Presidents of the Lombardy and Veneto regions. But in the South, Salvini had the opportunity to create a movement that was fully dependent on his leadership and reflective of his populist views. This was also possible because in the southern regions the League had never had a governing role (Vampa 2017: 36).

Salvini was also successful in promoting the transformation of the League because the party had already started paying increasing attention to themes that went well beyond its original regionalist mission. Within a clearly populist framework, the territorial agenda of the party was also combined with support for 'law and order' and anti-immigration policies. Generally, it seems that the 'us versus them' discourse of the LN changed over time. In the 1990s, when the main 'enemies' were the southern Italians, who were accused of 'exploiting' the northerners, the definitions of both 'us' (the northerners) and 'them' (the southerners) were clear and consistent with the territorial agenda of the party. In the 2000s, however, the increasing emphasis on immigration complicated the picture. The new 'them' was clearly represented by immigrants (from outside Italy) but also by EU institutions. At the same time, political attacks against southerners (and the political elite in Rome) became much rarer. Yet the party definition of 'us' remained more ambiguous and open to different interpretations. Was the party still defending and representing the exclusive interests of the Northerners? Was it instead promoting policies that could potentially appeal to all Italians?

Figure 5 is based on data from the Comparative Manifesto Project (Volkens et al. 2018; see also discussion of Figure 1). The data consider changes in various categories from the 1990s to $2000 \mathrm{~s} .{ }^{10}$ It clearly shows how the programmatic profile of the LN had already started to

\footnotetext{
${ }^{10}$ For 'Support for federalism/decentralisation' see note 3. Support for anti-immigration policies/traditional values/law and order' is measured by adding categories 601 (National way of life: positive), 603 (Traditional morality: positive), 605 (Law and order: positive), 608 (Multiculturalism: negative) and subtracting categories
} 
change from the 1990s to the 2000s. The declining role of the 'federalist' agenda is evident, as was also highlighted at the beginning of this article (Figure 1). Interestingly, this shift was accompanied by an increasing relevance of more anti-immigrant, law and order positions, which in the 2010s became clearly dominant. Additionally, the pro-European stance of the party disappeared in the 2000s (Chari et al 2004; Giordano 2004) and turned into clear Euroscepticism (negative score) in the 2010s.

\section{[Figure 5]}

In the 2000s, the programmatic transformation and differentiation of the $\mathrm{LN}$, its more marked anti-immigration and 'authoritarian' profile (Mudde 2007: 22-23), did not initially seem to threaten the core regionalist identity of the party and in fact was 'subsumed' into it (Elias, Szöcsik and Zuber 2015: 845). For more than 20 years, Bossi and his political history symbolised long-term aspirations for more regional autonomy, which were never fundamentally questioned by leadership, activists and supporters. The 'northern question' remained central for the party with important effects on the whole political and institutional system of Italy (Fargion 2005). Yet at the beginning of the 21st century, some elements of tension and ambiguity started to emerge: how is 'us' defined and translated into political actions if immigrants and non-Italian actors (rather than the southerners) are the main 'enemies', the new 'them'? In the stormy years that followed the downfall of the old leader, this question assumed increasing relevance and allowed Salvini to respond to the structural changes described in Stage 2 by transforming the party into a state-wide, nationalist force. Generally, we cannot fully understand the territorial shift of the League just by looking at changes in the political context, without considering how the party and its leaders re-interpreted other (initially) 'complementary' issues and how these assumed increasing importance over time.

The pre-crisis trajectory of CDC/CiU was different from the one followed by the League and this can help us refine the explanation of why, after the beginning of the crisis, this party has moved to more extreme territorial positions. As shown in Figure 6, which relies on the same manifesto categories considered in Figure 5, in the 1990s the political profile of CiU was very similar to the one of the League, not only on the centre-periphery dimension. Yet as its

602 (National way of life: negative), 604 (Traditional morality: negative), 607 (Multiculturalism: positive). 'Support for the EU/internationalism' is measured by adding categories 107 (Internationalism: positive) and 108 (European Community/Union: positive) and subtracting categories 109 (Internationalism: negative) and 110 (European Community/Union: negative). 
territorial focus increased in the 2000s and 2010s, the party did not clearly shift to the right (at least not as much as the League) on immigration and EU/international issues, in keeping with the broader absence of such a rightward shift on these issues at the time in Spain in general.

\section{[Figure 6]}

The beginnings of an evolution within CDC in the years prior to the 2007 financial crisis is essential to understanding CDC's eventual shift to a pro-sovereignty agenda in 2012. Moreover, the agency of Artur Mas himself is of particular importance in this regard. Like Salvini, who had to deal with the legacy of a strong former leader (Umberto Bossi), Mas was the successor of a prominent political personality, Jordi Pujol, who had dominated the party (and the Catalonian scene) for a very long period. Although the leadership change from Pujol to Mas was, at first, characterised by a continuation of moderate, accommodationist behaviour, Mas was well aware that the context in Catalonia was changing and CDC's electoral base was diminishing. His subsequent decision to take the party in a new direction can also be seen, to an extent, as part of an 'internal' strategy aimed at consolidating his new position and gaining political legitimacy in that changing context. The unexpectedly high participation in the 2012 pro-independence march on Catalan's national day, amid increasing pressure from highly organised pro-independence civil society groups with close links to the political class, may well have accelerated Mas's transformation of CDC into an explicitly pro-sovereignty party thereafter. And yet the seeds of this had in fact been in the making for a while. The shift can be seen as the culmination of the process of moving towards a 'national transition', a project Mas had started working on around 2006/2007 (Hugh 2014), when CiU was, for the first time, in opposition to a left-wing tripartite coalition governing Catalonia. Barrio and RodríguezTeruel (2017) interpret CiU's repeated attempts to outbid the ruling coalition - which also included the more territorially radical ERC - with more ambitious proposals of autonomy as an elite-led process of radicalisation in response to a climate of increasing party competition on the territorial axis.

In 2007, Mas had announced a relaunch of the Fundació Catalanista Demòcrata Trias Fargas (CatDem), a foundation linked to $\mathrm{CDC}$, with the aim to turn it into the 'casa grande del catalanismo' ('big home for Catalanism'). Aware that CDC's electoral base was diminishing even though it was still winning elections, Mas designed this new initiative to increase the 
party's social base and recover voters disenchanted with years of CiU-PP collaboration. ${ }^{11}$ This coincided with a time of generational change within CDC, with pro-sovereignty sectors of the party's youth organisation coming through the ranks. Mas wanted the 'casa' to bring together all those in politics and civil society interested in working on Catalonia's future, from those in favour of more self-government through to those in favour of full independence. After the experience of being forced into the backseat when the tripartite coalition took forward plans for a new Catalan statute of autonomy, CDC was determined to be prepared to play the lead role in taking forward a national and territorial agenda for Catalonia the next time the opportunity arose.

Moreover, the statute reform process itself had suggested that the viability of traditional accommodationist politics to seek gains for Catalonia was coming to an end. Many powers had already been devolved to the region, and not only the PP, but also many within the PSOE, were starting to feel that the devolution model had gone far enough. When CiU returned to power in Catalonia in 2010, forming a minority government, it did initially re-establish a working relationship with the PP, relying upon its support in the Catalan parliament to approve some fundamental areas of legislation, for example its 2012 regional budget. This relationship with the PP was, however, by then a very uncomfortable one for $\mathrm{CiU}$, and eventually became untenable following the PP's winning of an absolute majority in the Spanish parliament in 2011 and its implementation of an austerity agenda, crackdown on regional spending and attempts at recentralisation from then onwards. ${ }^{12}$ The time was ripe for a more dramatic shift in CDC's agenda.

CDC under Mas thus gradually evolved towards a pro-sovereignty stance in a step-by-step process, moving on to a new phase each time one was thwarted by Madrid: first the idea of a bilateral financing pact specifically for Catalonia, then the 'right to decide', then 'state structures' (with ambiguity intended, leaving open the possibility at first of whether or not this would imply full independence from Spain or an alternative arrangement within Spain), and finally an explicit pro-independence agenda. Following Mas's replacement as president by Carles Puigdemont (a longstanding committed pro-independence figure), the identity of the party, rebranded as the Catalan European Democratic Party (PDeCAT), was somewhat

\footnotetext{
${ }^{11}$ Personal interview with Agustí Colomines, 23 March 2015. See also, for example, El Mundo (2008).

${ }^{12}$ In personal interviews held with CDC representatives in 2016, they suggested that there was a strong feeling within the party against the alliances with the PP on this occasion, far more so than during the Pujol years of PP$\mathrm{CiU}$ collaboration.
} 
obscured by the rather ambiguous nature of the exact relationship between the party itself and the broader pro-independence platforms that Puigdemont spearheaded. First there was Junts per Catalunya (Together for Catalonia), comprising PDeCAT but also independents, created to contest the 2017 Catalan election. Puigdemont and his successor Quim Torra then launched another new platform in 2018, the Crida Nacional per la República (National Call for the Republic), the aim of which was to become an all-encompassing pro-independence movement bringing together different pro-independence parties and independents, regardless of their exact partisan affiliation. While the creation of the Crida risked diluting PDeCAT's own identity, still fledgling after the party's rebranding, it is interesting that this attempt to build an all-encompassing pro-sovereignty movement bears a marked parallel with the idea of creating a pan-Catalanist organisation that Mas had more than a decade previously when he set up the 'casa grande del catalanismo'. ${ }^{13}$

\section{Discussion and Conclusion}

Our comparative analysis started with a general description of the diverging territorial positions of two regionalist parties, the LN and CDC. Since the Great Recession, the latter has shifted to the extreme end of the centre-periphery dimension of political competition, whereas the former has almost completely abandoned its territorial agenda. We have analysed the process that led to this divergence, first looking at changes in the socio-economic context at the national and regional levels (stage 1) and then focusing on the impact that the crisis had on political opportunity structures (stage 2). We have also considered how new leaders responded to deep transformations in the political environment by accelerating intra-party processes of programmatic revision that had already started before the crisis (stage 3).

Table 1 summarises our findings. We have highlighted that the economic crisis was severe in both Italy and Spain but only in the latter did it contribute to a significant increase in the tensions between central and regional governments, particularly in Catalonia, one of the historic regions facing the greatest financial problems under the common financing system. This also shaped the process of party system restructuring. Whereas in Italy the new political challenger that emerged from the crisis, the M5S, neglected territorial issues, in Spain the two outsiders, Podemos and Ciudadanos, positioned themselves on the opposite sides of the centre-

\footnotetext{
${ }^{13}$ Mas himself has commented on this parallel (see, for example, El Periódico 2018).
} 
region conflict. This in turn affected the process of adaptation already being undertaken by the two key regionalist parties: the League in Italy and CDC in Spain. The change in political opportunity structures at national and subnational levels interacted with intra-party developments. In Italy, the new leader of the League, Matteo Salvini, dropped the federalist agenda and actively promoted the nationalisation of the party, pushing to the extreme the radical right-wing character of the party (focusing more on anti-immigration and anti-EU policies than decentralisation), which had already started to emerge in the early 2000s. In Spain, on the other hand, Artur Mas was under increasing pressure to abandon moderate pro-federalist stances.

\section{[Table 1]}

Yet these shifts were not merely passive adjustments to changing external circumstances in the wake of the financial crisis. As our analysis has shown, Salvini refused to re-politicise the centre-periphery cleavage even after regional branches of his own party organised autonomy referendums in Lombardy and Veneto and a civil society movement in the latter region mobilised in support of independence. On the other hand, Mas had already started reshaping some important elements of CDC's territorial agenda in the pre-crisis period due to a combination of internal and external pressures. This facilitated the party's move to the proindependence camp once the Great Recession had seriously altered political equilibriums and central-regional relations. Mas's successors further consolidated CDC's programmatic transformation. Therefore, while transformations in the political environment are important the changes observed in this paper would not have occurred in a context of stability -, they are not sufficient in explaining how parties shift their emphasis and position on specific policy dimensions - the territorial one in this specific case. Ultimately, political 'entrepreneurs' act as agents of change by relying on past legacies and exploiting a selected mix of intra-party and external conditions during a 'critical juncture'.

Although here we have tried to explain why the two parties followed different paths, it is undeniable that their transformations in turn had important effects on central-periphery political dynamics at the system-wide level in Italy and Spain. Going back to our framework summarised in Figure 2, we can see that changing positions of key political actors may have 
feedback effects on the political context. So, for instance, the radicalisation of CDC resulted in a hardening of the recentralising drive advocated not only by the mainstream PP but also, and particularly, the emerging Ciudadanos. From 2018, the worsening of centre-periphery tensions even contributed to the emergence of a new right-wing party, Vox. This party negates other nationalities and regional identities in Spain and primarily mobilises against centrifugal territorial tendencies coming from regions pushing for more autonomy or independence, Catalonia being the main target (Vampa 2020). More generally, competition in the Spanish general elections of April and November 2019 was heavily shaped by how all parties positioned themselves on the centre-periphery dimension (Gray 2020). On the other hand, the territorial moderation of the League, and its simultaneous radicalisation on the libertarian-authoritarian dimension (and on the EU 'transnational' cleavage), has contributed to the further decline of territorial issues in the Italian political debate. Thus, immigration (linked to the refugee crisis), taxation (introduction of a flat-tax) and social policy (introduction of a basic income) were the dominant issues of the 2018 general election campaign (Chiaramonte et al. 2018; Baldini and Nels Giglioli 2019). Even potentially disruptive episodes, like the autonomy referendums in Veneto and Lombardy mentioned above, failed to gain significant national attention (comparable to that of the Catalan crisis in Spain). If anything, the increasing 'nationalisation' of Italian political competition seems to be favouring the success of another radical right party, Brothers of Italy (FdI), which, together with Salvini's League, forms the Italian 'sovereignist' front (Basile and Mazzoleni 2020).

The scope of this comparative article is limited to two parties in two countries in the decade following the crisis. Yet its framework can be applied to other parties and country cases and to the analysis of future developments beyond the period considered. In Spain itself, while we have focused here on CDC as the largest regionalist party since the transition to democracy and therefore the most significant for wider territorial dynamics, the same framework can also be applied to explain why its closest equivalent in the Basque region, the Basque Nationalist Party (PNV), did not radicalise towards a pro-independence stance in the same way but rather postponed its quest for some degree of sovereignty for the Basque Country in the aftermath of the 2008 financial crisis (Gray 2020). Given the different nature of both the economic and fiscal model in the Basque Country, the impact of the financial crisis was not as hard on the region, and it was also the regional government's responsibility to address it (no scope to blame the central government under the model of near fiscal autonomy). The region also experienced differences in terms of political opportunity structures, shaped in part by pre-crisis political 
trends specific to the region, that help to explain the different trajectory of the PNV compared to $\mathrm{CDC}$.

Returning to the parties analysed in this paper, the divergence observed in 2008-2018 between the League and CDC (and its successors) could increase or decrease depending on changes in socio-economic and political contexts and on the strategies pursued by key political players in response to these changes. Systemic shocks in other countries might also lead to shifts in one direction or the other, similar to those of Italy or Spain, depending on context and actors. So, for instance, Brexit could lead to a repositioning of political parties on the centre-periphery dimension in the UK, with the re-emergence of pro-independence demands in Scotland, which the 2014 referendum seemed to have defused. Yet neither the Great Recession nor Brexit have been as disruptive as the shock that the whole world is currently facing. The crisis caused by the COVID-19 pandemic is once again hitting Italy and Spain particularly hard. It is too soon to provide an analysis of current developments but this critical juncture is likely to deeply affect all dimensions of politics, including the territorial one. 


\section{Data availability statement}

The data that support the findings of this study are available from the corresponding author upon reasonable request.

\section{Acknowledgments}

The authors wish to thank all the colleagues who provided comments on earlier drafts of this article during various workshops and conferences. The authors also wish to thank the editor and the anonymous reviewers for their insightful and constructive feedback.

\section{References}

Albertazzi, D., A. Giovannini and A. Seddone (2018). 'No regionalism please, we are Leghisti!' The transformation of the Italian Lega Nord under the leadership of Matteo Salvini. Regional \& Federal Studies 28(5): 647-671.

Arzheimer, K. and E. Carter (2006). Political opportunity structures and right-wing extremist party success. European Journal of Political Research 45(3): 419-443.

Asatryan, Z., L. P. Feld and B. Geys (2015). Partial fiscal decentralization and sub-national government fiscal discipline: empirical evidence from OECD countries. Public Choice 163(34): 307-320.

Barberà, O. and A. Barrio (2017). Moderate regionalist parties in Spain: Convergencia y Unió and Partido Nacionalista Vasco. In Mazzoleni, O. and S. Mueller (eds.), Regionalist Parties in Western Europe: Dimensions of Success. Abingdon: Routledge (61-85).

Barrio, A. and J. Rodríguez-Teruel (2017). Reducing the gap between leaders and voters? Elite polarization, outbidding competition, and the rise of secessionism in Catalonia. Ethnic and Racial Studies 40(10): 1776-1794.

Basile, L. and O. Mazzoleni (2020). Sovereign wine in populist bottles? An introduction. European Politics and Society 21(2): 151-162.

Biorcio, R. (2017). The Northern League. In Mazzoleni, O. and S. Mueller (eds.), Regionalist Parties in Western Europe: Dimensions of Success. Abingdon: Routledge (135-151).

Capoccia, G. and R.D. Keleman (2007). The Study of Critical Junctures: Theory, Narrative, and Counterfactuals in Historical Institutionalism. World Politics 59(3): 341-369.

Casal Bértoa, F. (2014). Seismic Wave or Tsunami? Assessing Party System Change in times of Crisis. 8th ECPR General Conference, Glasgow.

Castells, A. (2014). Catalonia and Spain at the crossroads: financial and economic aspects. Oxford Review of Economic Policy 30(2): 277-296. 
Ceccarini, L. and F. Bordignon (2017). Referendum on Renzi: The 2016 Vote on the Italian Constitutional Revision. South European Society and Politics 22(3): 281-302.

Cerruto, M. (2013). La delegittimazione della classe politica regionale. Istituzioni del Federalismo: Rivista di studi giuridici e politici 34(2): 477- 507.

Chari, R. S., S. Iltanen and S. Kritzinger (2004). Examining and Explaining the Northern League's 'U-Turn' from Europe. Government and Opposition 39(3): 423-450.

Chiaramonte, A., V. Emanuele, N. Maggini and A. Paparo (2018). Populist Success in a Hung Parliament: The 2018 General Election in Italy. South European Society and Politics 23(4): 479-501.

Colomer, J.M (2017). The venturous bid for the independence of Catalonia. Nationalities Papers 45(5): 950-967

De Lange, S. (2007). A New Winning Formula? The Programmatic Appeal of the Radical Right', Party Politics 13(4): 411-435.

Della Porta, D. (2008). Comparative analysis: case-oriented versus variable-oriented research. In Della Porta, D. and M. Keating (eds.), Approaches and Methodologies in the Social Sciences. Cambridge: Cambridge University Press (198-222).

De Winter, L. and H. Türsan (eds.) (1998). Regionalist Parties in Western Europe. London and New York: Routledge.

Diamanti, I. and J. Donaldson (1997). The "Lega Nord": From Federalism to Secession. Italian Politics 12: 65-81.

Dinas, E. (2012). Left and Right in the Basque Country and Catalonia: The Meaning of Ideology in a Nationalist Context. South European Society and Politics 17(3): 467-485.

Elias, A., E. Szöcsik and C.I. Zuber (2015). Position, selective emphasis and framing: How parties deal with a second dimension in competition. Party Politics, 21(6): 839-850

El Mundo (2008). “CDC se prepara para el congreso que consagrará la 'Gran Casa del Catalanismo"”. El Mundo, 11.07.2008.

El Periódico (2018). "Artur Mas: 'La Crida debería ser la casa grande del soberanismo"”. El Periódico, 22.11.2018.

Encarnación, O.G. (2009). Spain's New Left Turn: Society Driven or Party Instigated?. South European Society and Politics 14(4): 399-415.

Fargion, V. (2005). From the southern to the northern question. Territorial and social politics in Italy. In McEwen, N. and L. Moreno (eds.), The Territorial Politics of Welfare. London and New York: Routledge (127-147). 
Field, B.N. (2014). Minority Parliamentary Government and Multilevel Politics: Spain's System of Mutual Back Scratching. Comparative Politics 46(3): 293-312.

Giordano, B. (2004). The politics of the Northern League and Italy's changing attitude towards Europe. Perspectives on European Politics and Society 5(1): 61-79.

Giovannini, A. and D. Vampa (2019). Towards a new era of regionalism in Italy? A comparative perspective on autonomy referendums. Territory, Politics, Governance. Advanced online: https://doi.org/10.1080/21622671.2019.1582902 [accessed 30.10.2019].

Gómez, B., S. Alonso and L. Cabeza (2018). Regional Manifestos Project [Dataset]. Retrieved from www.regionalmanifestosproject.com [accessed 30.10.2019].

Gray, C. (2014). Smoke and mirrors: How regional finances complicate Spanish-Catalan relations. International Journal of Iberian Studies 27(1): 21-42.

Gray, C. (2016). Nationalist Politics and Regional Financing Systems in the Basque Country and Catalonia. Bilbao: Diputación Foral de Bizkaia, Departamento de Hacienda y Finanzas.

Gray, C. (2020). Territorial Politics and the Party System in Spain: Continuity and Change since the Financial Crisis. Abingdon: Routledge.

Hernández, E. and H. Kriesi (2016). The Electoral Consequences of the Financial and Economic Crisis in Europe. European Journal of Political Research 55(2): 203-224.

Hobolt, S.B. and J. Tilley (2016). Fleeing the centre: the rise of challenger parties in the aftermath of the euro crisis. West European Politics 39(5): 971-991.

Hutter, S., H. Kriesi and G. Vidal (2018). Old versus new politics: The political spaces in Southern Europe in times of crises. Party Politics 24(1): 10-22.

Keating, M. (2009). Second Round Reform. Devolution and constitutional reform in the United Kingdom, Belgium and Italy. LSE ‘Europe in Question’ Discussion Papers No. 15/2009.

Keating, M. and A. Wilson (2009). Renegotiating the State of Autonomies: Statute Reform and Multi-level Politics in Spain. West European Politics 32(3): 536-558.

Kitschelt, H. (1986). Political opportunity structures and political protest: Anti-nuclear movements in four democracies. British Journal of Political Science 16(1): 57-85.

Hutter, S. and H. Kriesi (eds.). European Party Politics in Times of Crisis. Cambridge: Cambridge University Press.

Marangoni, F. and L. Verzichelli (2015). From a Technocratic Solution to a Fragile Grand Coalition: The Impact of the Economic Crisis on Parliamentary Government in Italy. The Journal of Legislative Studies 21(1): 35-53.

Mudde, C. (2007). Populist Radical Right Parties in Europe. Cambridge: Cambridge University Press. 
Muro, D. (2009). Territorial Accommodation, Party Politics, and Statute Reform in Spain. South European Society and Politics 14(4): 453-468.

Rodden, J. (2005). Hamilton's Paradox: The Promise and Peril of Fiscal Federalism. New York: Cambridge University Press.

Scantamburlo, M., S. Alonso and B. Gómez (2018). Democratic regeneration in European peripheral regions: new politics for the territory? West European Politics 41(3): 615-639.

Schneider, M. and P. Teske (1992). Towards a Theory of the Political Entrepreneur: Evidence from Local Government. American Political Science Review 86(3): 737-747.

Vampa, D. (2017). Matteo Salvini's Northern League in 2016: between stasis and new opportunities. Italian Politics 32(1): 32-50.

Vampa, D. and R. Vignati (2017). I partiti e le campagne del NO. In Pritoni, A., M. Valbruzzi and R. Vignati (eds.), La prova del No: Il sistema politico italiano dopo il referendum costituzionale. Soveria Mannelli: Rubbettino (75-92).

Vampa, D. (2020). Competing forms of populism and territorial politics: the cases of Vox and Podemos in Spain. Journal of Contemporary European Studies. Online: https://doi.org/10.1080/14782804.2020.1727866

Verbeek, B., A. Zaslove and M. Rooduijn (2018). Italian Populism: Toppling and Re-building the Party System Twice. In Wolinetz, S. and A. Zaslove (eds.) Absorbing the Blow: Populist Parties and their Impact on Parties and Party Systems. London and New York: ECPR Press (197-222).

Vercesi, M. (2015). Owner parties and party institutionalisation in Italy: is the Northern League exceptional? Modern Italy 20(4): 395-410.

Volkens, A., P. Lehmann, T. Matthieß, N. Merz, S. Regel and B. Weßels (2018). The Manifesto Data Collection. Manifesto Project (MRG/CMP/MARPOR). Version 2018a. Berlin: Wissenschaftszentrum Berlin für Sozialforschung (WZB). Online: https://doi.org/10.25522/manifesto.mpds.2018a [accessed 30.10.2019]. 


\section{Biographies}

Davide Vampa is Senior Lecturer in Politics and International Relations at Aston University in Birmingham. He has published widely on multi-level party politics and public policy in Western Europe. He is the author of The Regional politics of welfare in Italy, Spain and Great Britain (Palgrave Macmillan, 2016). Email: d.vampa@aston.ac.uk

Caroline Gray is Lecturer in Politics and Spanish at Aston University in Birmingham, UK. She specialises in Spanish and wider European politics and is the author of Territorial Politics and the Party System in Spain: Continuity and Change since the Financial Crisis (Routledge, 2020). Email: c.gray1@aston.ac.uk 
Figure 1. Party manifestos: diverging positions on federalism/decentralisation from 1990s to 2010s

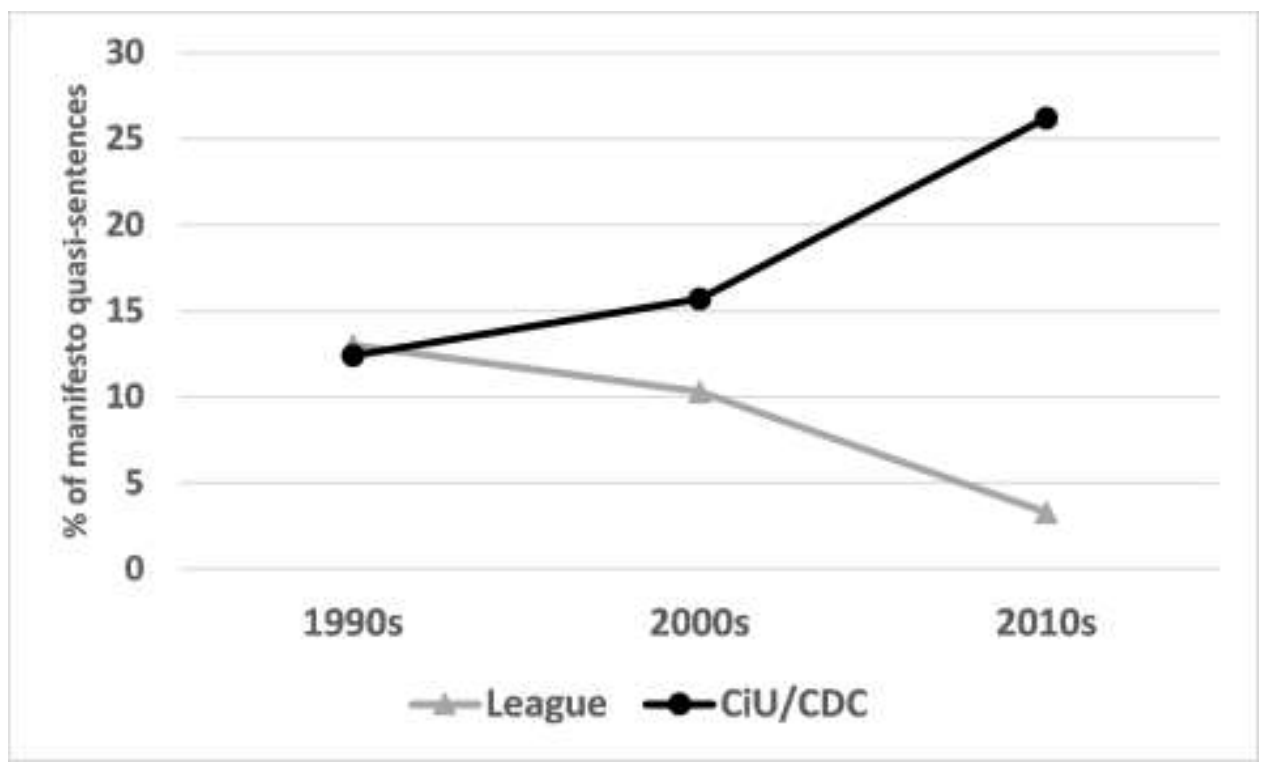

Source: comparative manifesto project. Authors' own calculations based on the share of manifesto quasi-sentences supporting a move of authority from the centre to the periphery. 2010s election up to 2018 in Italy and 2016 in Spain (2019 data not available but CDC was dissolved after 2016 election) 
Figure 2. From socio-economic crisis to changing party position on the 'territorial' dimension: structural changes and the role of political agency

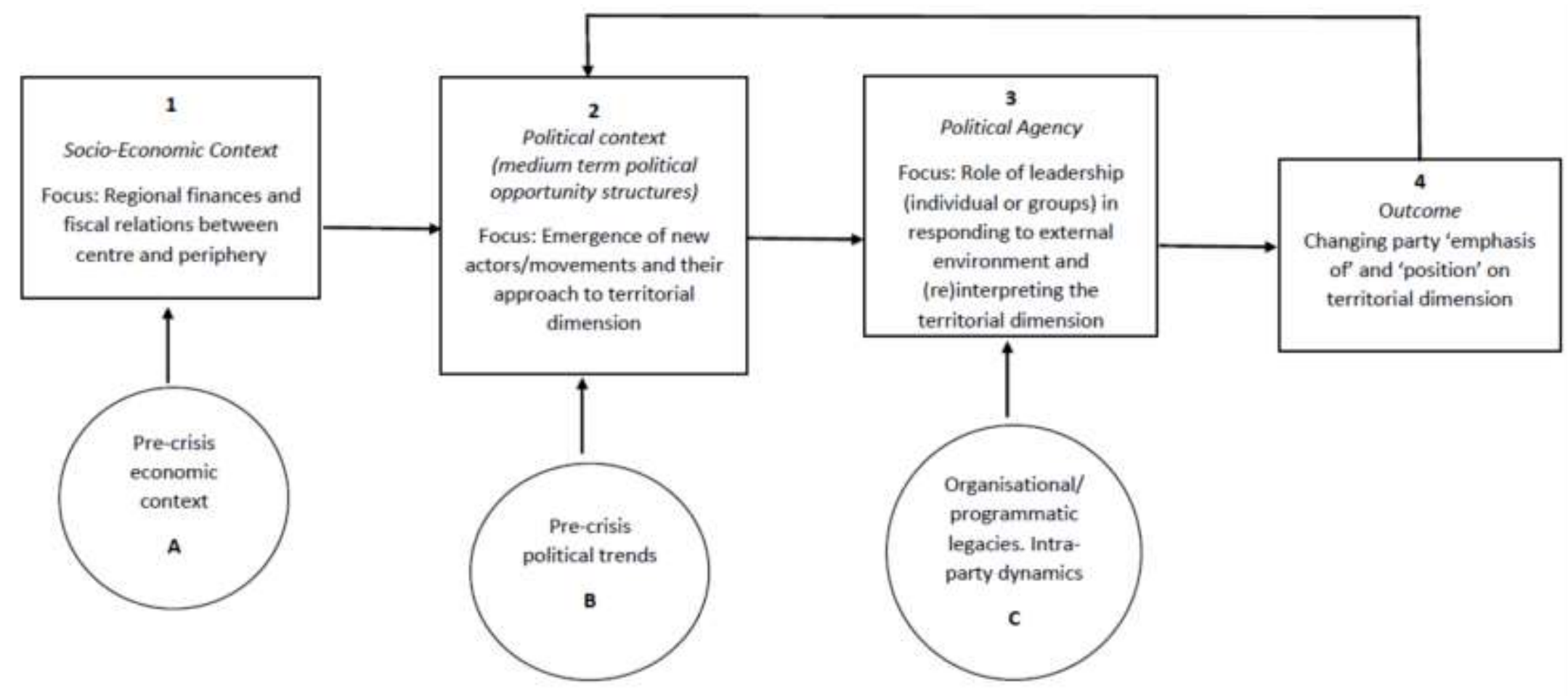


Figure 3. Deficit as \% of Revenues in Spanish Autonomous Communities and Italian Regions: Averages Before (2000-2007) and After (2008-2015) the Crisis

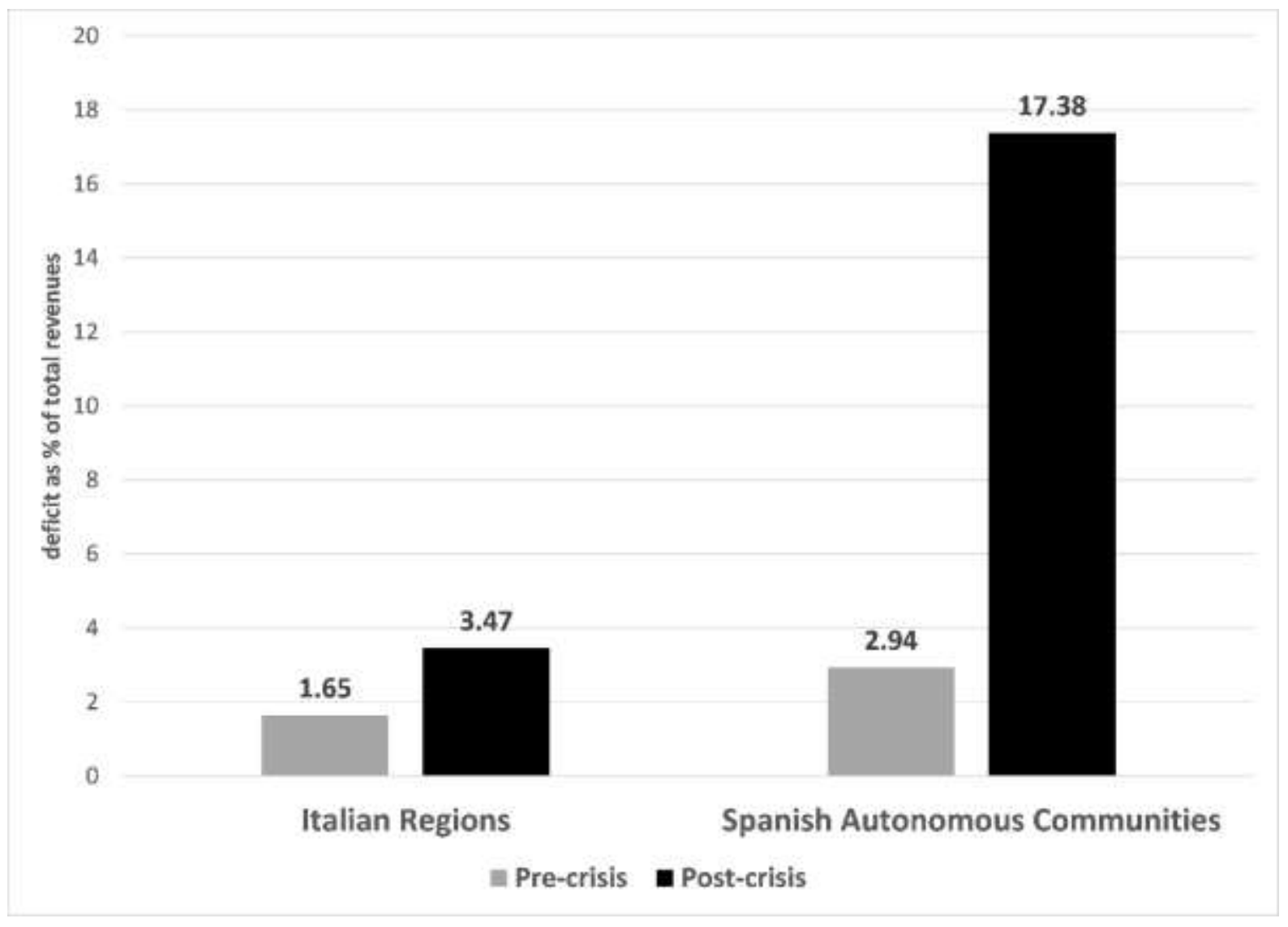

Sources: Intervención General de la Administración del Estado and Ministerio de Hacienda y Función Pública (for Spain); Agenzia per la Coesione Terrioriale and Istituto Nazionale di Statistica (for Italy). 
Figure 4. Centre-Periphery Cleavage: Saliency and Position of Ciudadanos and Podemos in Catalonia and M5S in Lombardy, Veneto and Piedmont

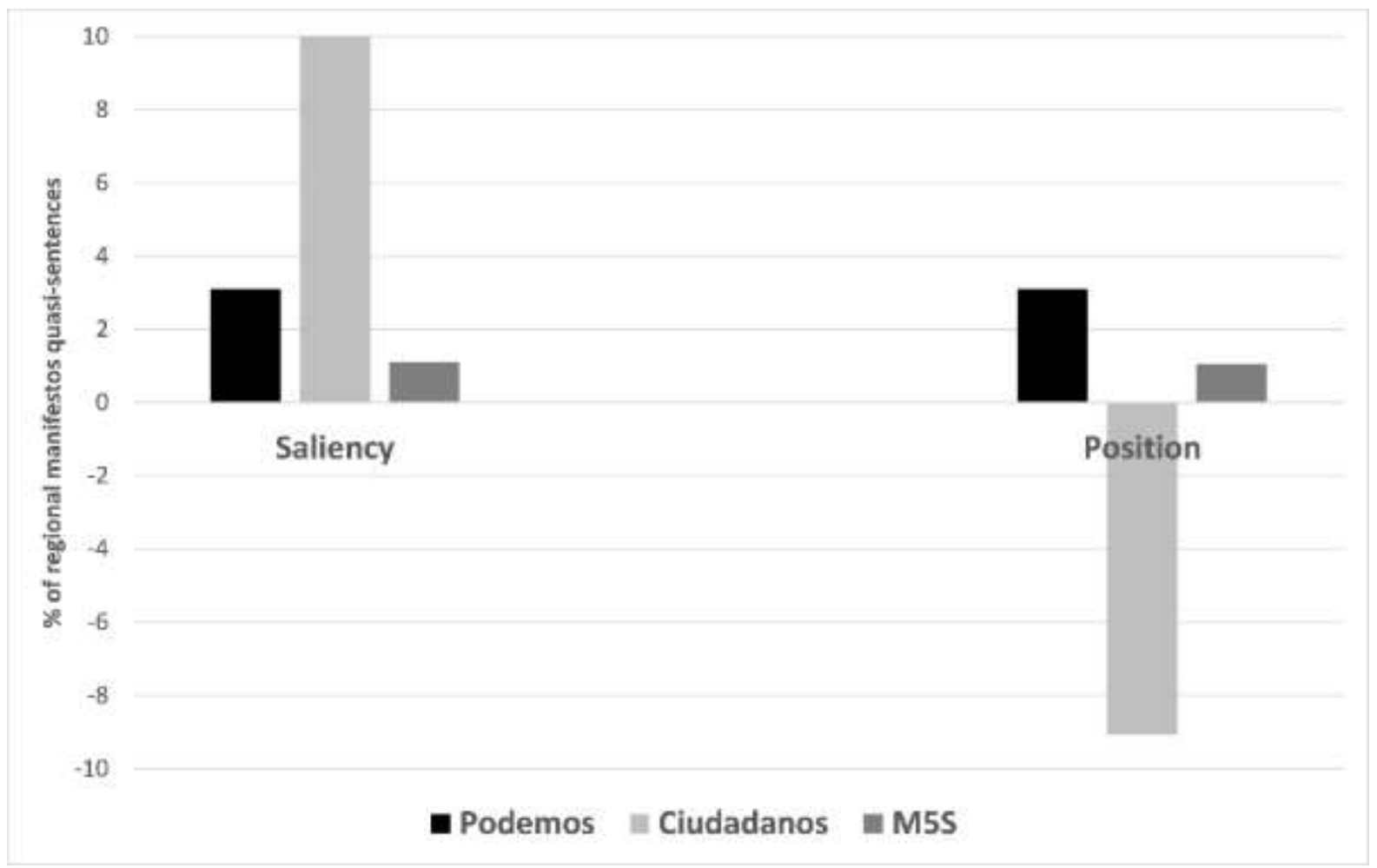

Source: Regional Manifesto Project. Percentage of manifestos’ quasi-sentences. 
Figure 5. The programmatic transformation of the LN: territorial politics, social conservatism, Europe

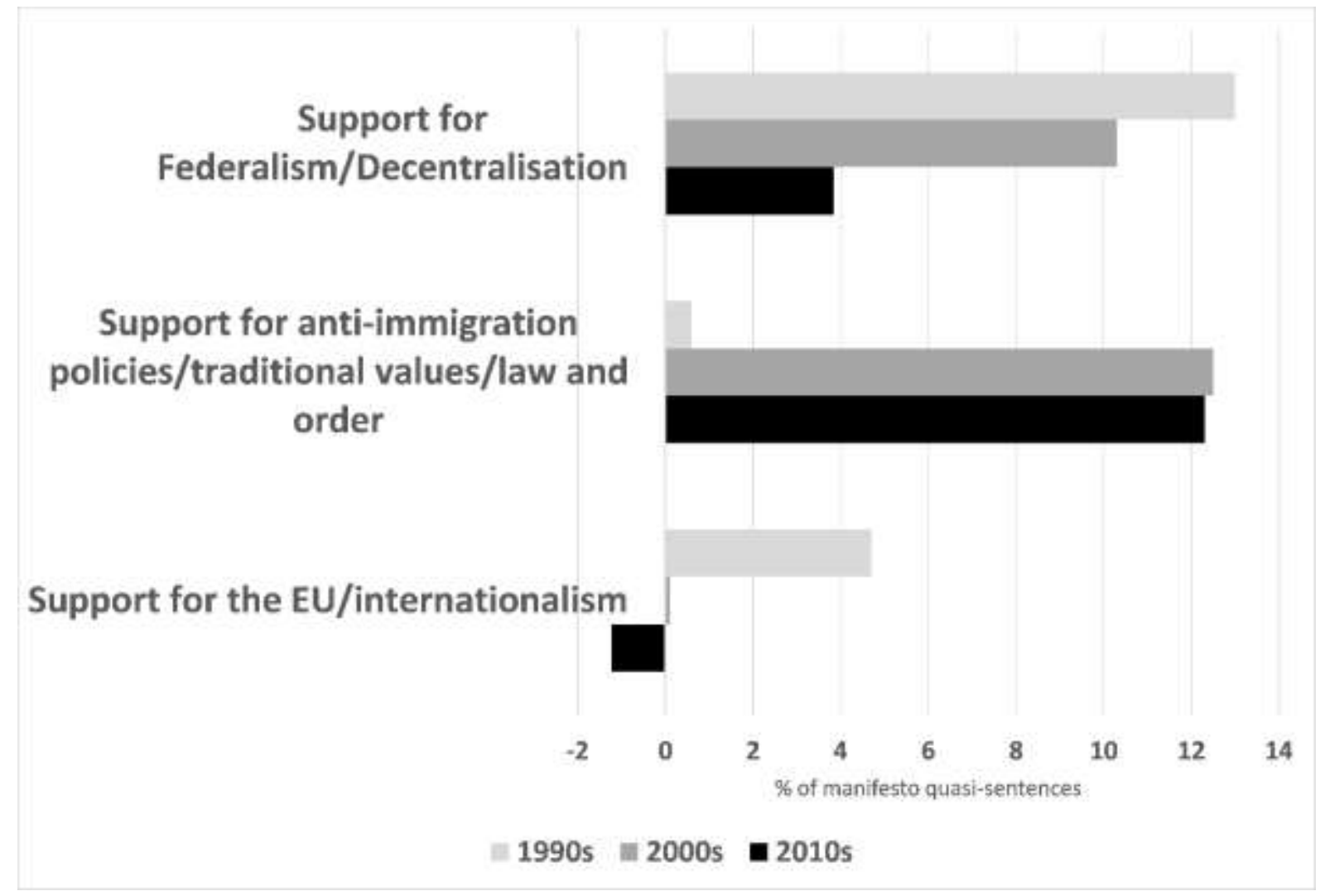

Source: Comparative Manifesto Project. 
Figure 6. The programmatic transformation of the CDC (CiU): territorial politics, social conservatism, Europe

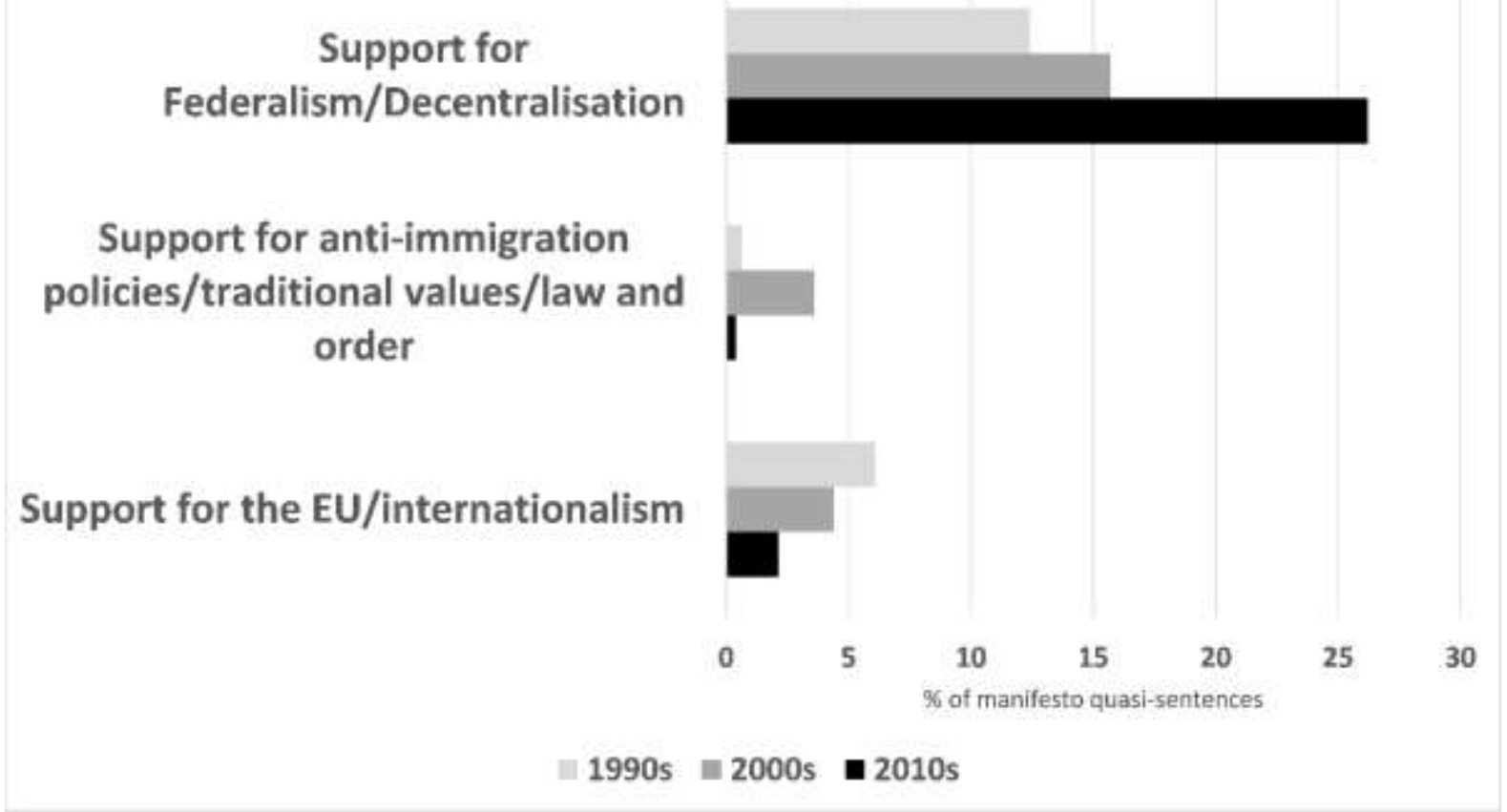

Source: Comparative Manifesto Project (up until 2016; 2019 data not available but CDC was dissolved after 2016 election) 
Table 1. Summary. League and CDC: from similarity to divergence

\begin{tabular}{|c|c|c|c|c|c|c|c|c|}
\hline \multirow[t]{2}{*}{ Parties } & \multirow[t]{2}{*}{$\begin{array}{l}\text { Pre-crisis similar } \\
\text { position }\end{array}$} & \multicolumn{2}{|c|}{$\begin{array}{l}\text { Stage 1. Socio-economic } \\
\text { context after } 2008\end{array}$} & \multicolumn{2}{|c|}{$\begin{array}{l}\text { Stage 2. Political context after } \\
2008\end{array}$} & \multicolumn{2}{|c|}{$\begin{array}{l}\text { Stage 3. Political agency (party } \\
\text { leadership) after } 2008\end{array}$} & \multirow{2}{*}{$\begin{array}{l}\text { Post-crisis } \\
\text { different } \\
\text { outcome }\end{array}$} \\
\hline & & Similarities & Differences & Similarities & Differences & Similarities & Differences & \\
\hline $\begin{array}{l}\text { League } \\
\text { (Italy) }\end{array}$ & Regionalist party & \multirow[t]{2}{*}{$\begin{array}{l}\text { Eurozone } \\
\text { 'periphery', } \\
\text { serious } \\
\text { recession, } \\
\text { financial } \\
\text { constraints }\end{array}$} & $\begin{array}{l}\text { Regional } \\
\text { finances not } \\
\text { seriously } \\
\text { affected }\end{array}$ & \multirow{2}{*}{$\begin{array}{l}\begin{array}{l}\text { Crisis of } \\
\text { established } \\
\text { party system }\end{array} \\
\text { Pro- } \\
\text { autonomy/ } \\
\text { pro- } \\
\text { independence } \\
\text { bottom-up } \\
\text { movements } \\
\text { (Catalonia, } \\
\text { Veneto, } \\
\text { Lombardy) }\end{array}$} & $\begin{array}{l}\text { New actor } \\
\text { (M5S) is not } \\
\text { clearly } \\
\text { positioned on } \\
\text { centre- } \\
\text { periphery } \\
\text { cleavage }\end{array}$ & \multirow{2}{*}{$\begin{array}{l}\text { New leaders' } \\
\text { attempts to } \\
\text { strengthen } \\
\text { their political } \\
\text { legitimacy } \\
\text { Neither party } \\
\text { involved in } \\
\text { national } \\
\text { government } \\
\text { formation } \\
\text { after } 2011\end{array}$} & $\begin{array}{l}\text { Leader } \\
\text { promotes } \\
\text { radicalisation } \\
\text { of nativism } \\
\text { and } \\
\text { Euroscepticism }\end{array}$ & $\begin{array}{l}\text { 'State-wide' } \\
\text { Populist } \\
\text { Radical Right } \\
\text { Party }\end{array}$ \\
\hline $\begin{array}{l}C D C \\
\text { (Spain) }\end{array}$ & Regionalist party & & $\begin{array}{l}\text { Regional } \\
\text { finances } \\
\text { seriously } \\
\text { affected. } \\
\text { Tensions } \\
\text { between } \\
\text { Catalonia and } \\
\text { central } \\
\text { government }\end{array}$ & & $\begin{array}{l}\text { New actors } \\
\text { (Podemos, } \\
\text { Ciudadanos) } \\
\text { are clearly } \\
\text { positioned on } \\
\text { centre- } \\
\text { periphery } \\
\text { cleavage }\end{array}$ & & $\begin{array}{l}\text { Leader } \\
\text { promotes } \\
\text { radicalisation } \\
\text { of territorial } \\
\text { agenda }\end{array}$ & $\begin{array}{l}\text { Pro- } \\
\text { independence } \\
\text { party }\end{array}$ \\
\hline
\end{tabular}

